\title{
Sequence and phylogentic analysis of MERS-CoV in Saudi Arabia, 2012-2019
}

\author{
Mohamed A. Farrag ${ }^{1}$, Haitham M. Amer ${ }^{2}$, Rauf Bhat ${ }^{1}$ and Fahad N. Almajhdi ${ }^{*}$
}

\begin{abstract}
Background: The Middle East Respiratory Syndrome-related Coronavirus (MERS-CoV) continues to exist in the Middle East sporadically. Thorough investigations of the evolution of human coronaviruses (HCoVs) are urgently required. In the current study, we studied amplified fragments of ORF1a/b, Spike (S) gene, ORF3/4a, and ORF4b of four human MERS-COV strains for tracking the evolution of MERS-CoV over time.

Methods: RNA isolated from nasopharyngeal aspirate, sputum, and tracheal swabs/aspirates from hospitalized patients with suspected MERS-CoV infection were analyzed for amplification of nine variable genomic fragments. Sequence comparisons were done using different bioinformatics tools available.

Results: Several mutations were identified in ORF1a/b, ORF3/4a and ORF4b, with the highest mutation rates in the $S$ gene. Five codons; 4 in ORF1a and 1 in the $S$ gene, were found to be under selective pressure. Characteristic amino acid changes, potentially hosted and year specific were defined across the $S$ protein and in the receptor-binding domain Phylogenetic analysis using $S$ gene sequence revealed clustering of MERS-CoV strains into three main clades, $A, B$ and $C$ with subdivision of with clade B into B1 to B4.
\end{abstract}

Conclusions: In conclusion, MERS-COV appears to continuously evolve. It is recommended that the molecular and pathobiological characteristics of future MERS-CoV strains should be analyzed on regular basis to prevent potential future outbreaks at early phases.

Keywords: Human coronaviruses, Mutation, Viruses, Sequence analysis, Evolution

\section{Background}

Coronaviruses (CoVs) have long been known to infect humans and several animal species, causing systemic infections of respiratory airways, intestine, liver, and nervous system [1, 2]. Previously, human CoVs such as $\mathrm{HCoV}-229 \mathrm{E}, \mathrm{HCoV}-\mathrm{NL} 63, \mathrm{HCoV}-\mathrm{OC} 43$ and HCoVHKU1 were known to cause mild and self-limiting respiratory diseases mainly upper respiratory tract infections in the human population. Nevertheless, three outbreaks due to human CoVs have been already witnessed in the last two decades. The first outbreak caused by SARS-CoV-1

*Correspondence: Vrg_ksu@yahoo.com

${ }^{1}$ Department of Botany and Microbiology, College of Science, King Saud University, Riyadh 11451, Saudi Arabia

Full list of author information is available at the end of the article originated in China and gradually spread to several countries around the world leading to the death of 774 (9.56\%) cases out of 8096 reported to the World Health Organization [3]. The causative agent of the second outbreak was identified as MERS-CoV which was originated in Saudi Arabia in September 2012, and spread to the neighboring countries and further to other geographically distant regions [4-6].

According to WHO, MERS-CoV outbreak is on-going causing 2519 laboratory-confirmed cases till now, of which 866 (34.3\%) have died, majority of them in Saudi Arabia. Clinical manifestations of MERS-CoV are similar to those of SARS, nevertheless, MERS-CoV patients mostly develop rapid respiratory failure [5]. The third and the biggest pandemic started in Wuhan, China, in December, 2019. During 1 year since the reporting of 
the first case, SARS-CoV-2 has affected more than 215 countries with more than 55 million cases. Of these, more than 1.3 million have died with a case fatality rate of more than 2\% [7]. Bats are the common reservoir for several beta coronaviruses from which the virus jump to humans through an intermediate hosts [8-10]. However, in case of MERS-CoV, human infections are thought to occur directly from bats or through an intermediate host, most likely dromedary camels [11-13].

MERS-CoV belongs to the subfamily Orthocoronavirinae, family Coronaviridae, and order Nidovirales. Viruses of this family are enveloped with polycistronic, non-segmented, positive sense, single-stranded, RNA ( $30 \mathrm{kbp})$. According to ICTV, Orthocoronavirinae has four genera; Alphacoronavirus, Betacoronavirus, Gammacoronavirus, and Deltacoronavirus [14, 15]. Full genome sequence analysis allocated MERS-CoV among betacoronaviruses lineage $C$, a group that include bat-CoVs $[13,16]$. MERSCoV's genome was predicted to contain 10 ORFs with the first $5^{\prime}$-three-fourths sequence encodes for RdRp (ORF1a and ORF1b) [16]. These two ORFs are translated via -1 ribosomal frameshifting to yield polyproteins pp1a and pp1b which are processed into 16 nonstructural proteins (nsps) $[17,18]$. The last third ORFs are downstream ORF1b and encode for the structural proteins; spike $(\mathrm{S})$, envelop $(\mathrm{E})$, membrane $(\mathrm{M})$ and nucleocapsid $(\mathrm{N})$. Among these proteins, $S$ protein mediates virus entry via attachment to dipeptidyl peptidase 4 (DPP4) $[19,20]$. Therefore, $\mathrm{S}$ protein is among the highly variable MERS$\mathrm{CoV}$ proteins and hence, a target for phylogenetic studies and designing therapeutic agents.

MERS-CoV transmission, evolution, divergence and animal reservoir are critical issues that should be resolved for effective control of MERS-CoV and potentially for the current SARS-CoV-2 pandemic. CoVs are known for a high rate of recombination, a feature that enables them to infect several hosts and to fit well in different environmental niches [21-23]. Phylogenetic analysis based on the deduced amino acid sequences of the RdRp domain (ORF1ab, ORF1b) and conserved regions of structural proteins ( $\mathrm{S}, \mathrm{E}, \mathrm{N}$ and $\mathrm{M}$ ) revealed that MERS-CoV is closely related to HCoV-HKU4 and HCoV-HKU5 [14, 24, 25]. Moreover, MERS-CoV shares high sequence identity with bat CoVs from Africa, Europe and America [24, 26]. In the current study, four MERS-CoV isolates of human origin were used for sequence and phylogenetic analysis. Sequence contigs of 6916 nts including ORF1a/b, S, and ORF3/4a were amplified, sequenced and assembled. Sequence analysis was performed and mutations were recorded along the whole sequence contigs. Codons under selective pressure were investigated. Phylogenetic analysis was performed based on the $\mathrm{S}$ gene.

\section{Materials and methods Clinical samples}

Nasopharyngeal aspirate and/or swab samples were obtained from hospitalized patients with suspected MERS-CoV infection at three different cities in Saudi Arabia: Riyadh, Madinah and Dammam. Sputum and tracheal swabs/aspirates were also considered in few cases. A wide spectrum of clinical symptoms was included as probable signals for MERS-CoV infection including fever, myalgia, cough, dyspnea, aches, abdominal pain, vomiting and diarrhea. Samples were collected and handled by the relevant authorities at the Saudi Ministry of Health (MOH-SA) during December 2014 and January 2015 following the strict biosafety guidelines set by WHO and CDC $[7,27]$. Samples were transported in viral transport medium to the regional laboratories of $\mathrm{MOH}-\mathrm{SA}$ and processed immediately or stored at $-80{ }^{\circ} \mathrm{C}$ till use. Informed consents were obtained from the patients or their guardians and the study protocols were prepared to conform to the 1975 Declaration of Helsinki.

\section{RNA extraction and real-time RT-PCR}

Upon receipt, samples were shacked vigorously and equal volumes of sample and external lysis buffer (6 M Guanidine Isothiocyanate, 30\% Triton X-100, $100 \mathrm{mM}$ Tris$\mathrm{HCl}, 0.01 \%$ Bromophenol blue) were mixed in a safety cabinet. Clinical samples were extracted using one of two automatic nucleic acid isolation systems according to their availability in different $\mathrm{MOH}-\mathrm{SA}$ regional laboratories including: MagNA Pure 96 (Roche Diagnostics, Indianapolis, IN) and QIAsymphony SP (Qiagen, Hilden, Germany). MagNA Pure Compact Nucleic Acid Isolation (Roche) and QIAsymphony RNA (Qiagen) kits were utilized for viral RNA extraction in the corresponding platform according to the manufacturer's instructions. Single negative control of PCR grade water was extracted in parallel for every 12 samples. All samples were screened for MERS-CoV using LightMix ${ }^{\circledR}$ Modular MERS-CoV upE Kit (Roche) using the experimental protocol and reaction setup primarily established by Corman et al. [28]. Positive results were confirmed with LightMix ${ }^{\circledR}$ Modular MERSCoV ORF1a Kit (Roche). Samples with doubtful results (i.e. positive reactivity in one assay and negative in the other) were re-extracted and tested in triplicates in both UpE and ORF1a assays.

\section{Generation of sequence data}

RNA isolated from MERS-CoV positive samples was used for amplification of nine genomic fragments that possess considerable sequence variability among MERS$\mathrm{CoV}$ strains circulating worldwide in man and animals. The nine fragments include four for ORF1a/b, three for $\mathrm{S}$ gene, one for ORF3/4a and one for ORF4b (Table 1, 
Table 1 Primers used for amplification of sequencing fragments

\begin{tabular}{|c|c|c|c|c|c|}
\hline $\begin{array}{l}\text { Amplification } \\
\text { fragment }\end{array}$ & Target gene & $\begin{array}{l}\text { Primer name, position* } \\
\text { and sense }\end{array}$ & Primer sequence $\left(5^{\prime}-3^{\prime}\right)$ & $\begin{array}{l}\text { Expected size } \\
\text { (bp) }\end{array}$ & References \\
\hline \multirow[t]{2}{*}{1} & \multirow[t]{2}{*}{ ORF1a } & MERS-3047 (+) & ACT GCG TGG AAT GCC GATTC & \multirow[t]{2}{*}{843} & \multirow[t]{2}{*}{ This study } \\
\hline & & MERS-3890 (-) & GCC TAC GAC ATG CAG GAT ATT C & & \\
\hline \multirow[t]{2}{*}{2} & \multirow[t]{2}{*}{ ORF1a } & MERS-8089 (+) & CAA CAT TCA TTG ACG CAG CAC & \multirow[t]{2}{*}{946} & \multirow[t]{2}{*}{ [35] } \\
\hline & & MERS-9034 (-) & GGA TCA TGG CAG TAT GGT GTC & & \\
\hline \multirow[t]{2}{*}{3} & \multirow[t]{2}{*}{ ORF1a } & MERS-11419(+) & CAA GCC CCA TTG CCT ATC TG & \multirow[t]{2}{*}{646} & \multirow[t]{2}{*}{ [34] } \\
\hline & & MERS-12064 (-) & GCT TGA AGT ACG CTA GGA GTG & & \\
\hline \multirow[t]{2}{*}{4} & \multirow[t]{2}{*}{ ORF1b } & MERS-18791 (+) & CAT CAA GGA GCT CAT GTG GC & \multirow[t]{2}{*}{792} & \multirow[t]{2}{*}{ [35] } \\
\hline & & MERS-19582 (-) & TTC CAA ACC TTG AAC TTTTGT AAA AG & & \\
\hline \multirow[t]{2}{*}{5} & \multirow[t]{2}{*}{ Spike } & MERS-21425 (+) & CTG TCG CAG GGT AAG TTA CTT ATC & \multirow[t]{2}{*}{756} & \multirow[t]{2}{*}{ This study } \\
\hline & & MERS-22180 (-) & GTG TAC ATA AAG GTG CAG TTA CG & & \\
\hline \multirow[t]{2}{*}{6} & \multirow[t]{2}{*}{ Spike } & MERS-22116 (+) & CGT AAT GCC AGT CTG AAC TC & \multirow[t]{2}{*}{918} & \multirow[t]{2}{*}{ [34] } \\
\hline & & MERS-23032 (-) & CAG GGT GAG TAT TGA TTA GCG & & \\
\hline \multirow[t]{2}{*}{7} & \multirow[t]{2}{*}{ Spike } & MERS-22990 (+) & CTG AAG TAC CTC AGTTAG TGA ACG & \multirow[t]{2}{*}{1225} & \multirow[t]{2}{*}{ This study } \\
\hline & & MERS-24214 (-) & GCT GAT GCT GGA CCTTGC TG & & \\
\hline \multirow[t]{2}{*}{8} & \multirow[t]{2}{*}{ ORF3/4a } & MERS-25465 (+) & GTG ATA GAT ACG AGG AAT ACG ACC & \multirow[t]{2}{*}{780} & \multirow[t]{2}{*}{ This study } \\
\hline & & MERS-26001 (-) & GGA TAG CTG ACA GTT CCA CAG & & \\
\hline \multirow[t]{2}{*}{9} & \multirow[t]{2}{*}{ ORF4b } & MERS-26042 (+) & CTTTGG CCA AAC AGG ACG CA & \multirow[t]{2}{*}{536} & \multirow[t]{2}{*}{ [34] } \\
\hline & & MERS-26856 (-) & GAC GCC GAG AAA GCC ATA GTT C & & \\
\hline
\end{tabular}

ORF = open reading frame, MERS = Middle East Respiratory Syndrome, $b p=$ base pair

* Positions are relevant to the complete genome sequence of Human betacoronavirus 2c EMC/2012 (GenBank accession number JX869059)

Fig. 1). Amplification was performed in a single step RTPCR using SuperScript ${ }^{\circledR}$ III One-Step RT-PCR System with Platinum ${ }^{\circledR}$ Taq DNA Polymerase (Life Technologies, Carlsbad, CA). The cycling protocol involved: one cycle at $55^{\circ} \mathrm{C}$ for $30 \mathrm{~min}$, one cycle at $94^{\circ} \mathrm{C}$ for $2 \mathrm{~min}, 40$ cycles of $94^{\circ} \mathrm{C}$ for $15 \mathrm{~s}, 55^{\circ} \mathrm{C}\left(58{ }^{\circ} \mathrm{C}\right.$ for fragments 1,5 , 8 and 9) for $30 \mathrm{~s}$ and $68^{\circ} \mathrm{C}$ for $1 \mathrm{~min}$, and one cycle at $68^{\circ} \mathrm{C}$ for $10 \mathrm{~min}$. The amplified fragments were purified using QIAquick PCR purification kit (Qiagen) and were sequenced on both strands using BigDye Terminator version 3.1 sequencing kit on ABI PRISM 3730xl genetic analyzer at GATC Biotech (Cologne, Germany). The sequence of the nine regions was edited using Bioedit software, version 7.2.5 (Ibis Biosciences, Carlsbad, CA) and was assembled in a concatenated sequence of 6916 bases (around 23\% of the genome length).

\section{Sequence and phylogenetic analysis}

The complete genome sequence of 92 MERS-CoV Saudi and international strains (67 of human-origin and 25 of camel-origin) were retrieved from the GenBank database. Strains were chosen to represent the different MERS$\mathrm{CoV}$ genotypes $[29,30]$, the variable geographic regions worldwide, and the entire period of virus spread (2012 to 2019). Sequences were edited and trimmed using Editseq program of Lasergene software, version 3.18 (DNAStar, Madison, WI) to display concatenated sequences corresponding to those generated in the current study.

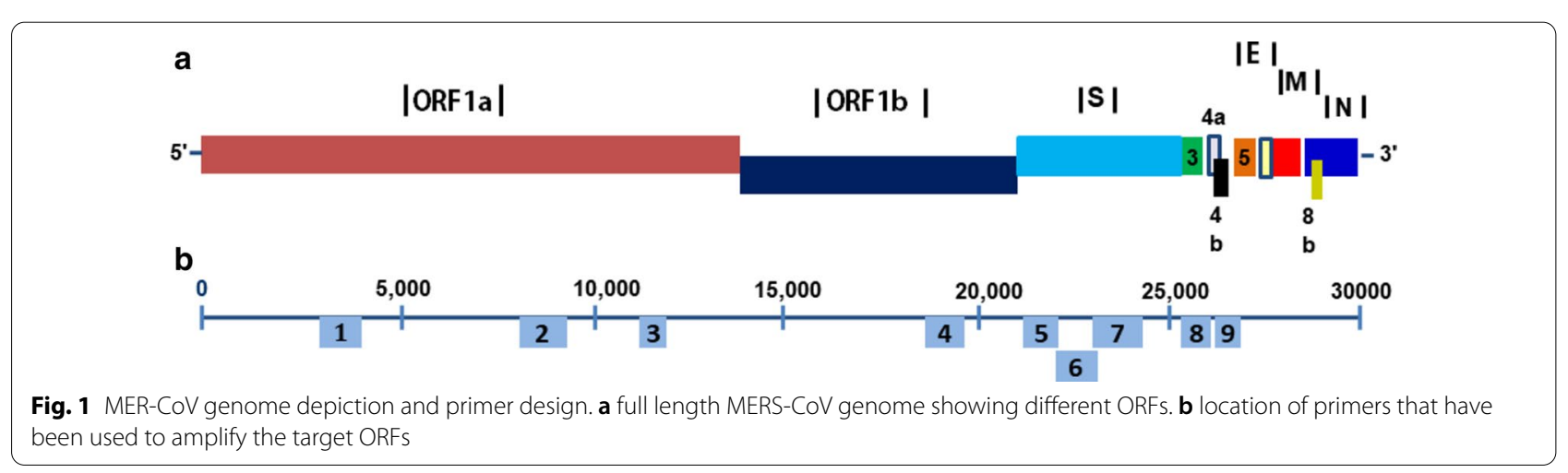


Multiple sequence alignment for divergence analysis, identification of mutation sites, and prediction of amino acid substitutions was performed using Clustal W algorithm, MegAlign program, Lasergene v3.18. Heterogeneity in the glycosylation profiles of all MERS-CoV stains was assessed by determining the potential $\mathrm{N}$ - and O-linked glycosylation sites using Net-N-glyc 1.0 (http:// www.cbs.dtu.dk/ services/NetNGlyc) and Net-O-glyc 3.1 (http://www.cbs. dtu.dk/services/NetOGlyc), respectively [31]. The phylogenetic tree was constructed based on both 2670 nts of the $\mathrm{S}$ gene. Phylogenetic analysis was accomplished using the maximum likelihood (ML) method of MEGA 6.0 software with bootstrapping of 1000 pseudo-replicates.

\section{Analysis of selective pressure}

To investigate the evolutionary dynamics, identify and allocate statistically significant positive and negative selective pressure sites, codons over the entire concatenated sequence were screened using DataMonkey server (http://www.datamonkey.org) [32, 33]. Four different models were employed for such purpose including: (1) single likelihood ancestor counting (SLAC), which uses a combination of ML and counting approaches to determine $\mathrm{dN} / \mathrm{dS}$ substitution rates per-site basis for coding sequence alignment and its phylogeny, (2) fixed effects likelihood (FEL), (3) random effects likelihood (REL), (4), mixed effects model of evolution (MEME), which was applied to allocate positively selected sites among different clades within a phylogenetic tree. Sites with a statistical $p$-value of $<0.1$ were considered under positive selection.

\section{Nucleotide sequence accession numbers}

The nucleotide sequence of the different genome fragments of MERS-CoV strains analyzed in this study have been deposited in GenBank under the following accession numbers: KT624236-KT624239 (ORF1a/b), KT624240-KT624243 (Spike gene), KT624244KT624247 (ORF3), and KT624248-KT62451 (ORF4b).

\section{Results}

\section{Sequence analysis, mutation record and glycosylation profile}

Multiple alignment of the assembled concatenated sequence of the four Saudi MERS-CoV strains revealed no abnormal sequence variations like gaps, insertions, and/or deletions. The overall nucleotide and deduced amino acid sequence homology ranged from 99.1 to $100 \%$ and from 98.8 to $100 \%$, respectively. A total of 27 mutations were recognized, among which 7 mutations changed their corresponding amino acid residues (Table 2$)$. The majority of mutations $(n=14)$ was identified in $\mathrm{S}$ protein gene. To track the evolution of $\mathrm{S}$ and ORF1a/b proteins throughout the years 20122019, the deduced amino acid sequences of all analyzed sequences were compared to EMC-2012; the first MERS$\mathrm{CoV}$ isolate. The spike protein seemed to be conserved among all the tested strains with about $99 \%$ sequence homology. Some amino acid changes appear characteristic to specific sub-clusters including: V27A, G159Y, H194Y, S390F, L450F A597V, R626P, L745F for MERSCoVs of Ethiopian camels (2017), V27L for Riyadh and Qaseem human isolates (2018), L411F for isolates of Riyadh (2014), A756Q, E666K and M696T for camel isolates of UAE and Egypt (2014). More importantly, the receptor binding domain (RBD) of the $\mathrm{S} 1$ protein subunit (residues 358 to 588) displayed amino acid changes in several MERS-CoV strains, such as K369I in Camel-Jeddah-O47(b)-2017, S390F in strains of Ethiopian camels, S457G in KFU-HKU-19dam-2013, S460F in Qatar-32013, A434S in Camel-Egypt-NRCE-HKU-205, Y447X in Camel-UAE-D1209-2015, and D509G in both Bisha-2012 and Riaydh-1-2012 strains (Fig. 2a).

ORF1a/b showed a distinct pattern where several amino acids had been changed permanently in comparison with the isolate (EMC-2012); $1000 \mathrm{~T} / \mathrm{V}, 1055 \mathrm{P} / \mathrm{S}$, $1070 \mathrm{~A} / \mathrm{E}, 1094 \mathrm{~N} / \mathrm{S}, 2747 \mathrm{~A} / \mathrm{V}$ and $2780 \mathrm{~A} / \mathrm{V}$ (Fig. 2b). Two amino acid changes, $981 \mathrm{G} / \mathrm{S}$, and $1099 \mathrm{P} / \mathrm{R}$, were found to be characteristic to the isolates of 2018 and 2019. Similarly, isolates of 2016 have one characteristic amino acid change at $1052 \mathrm{P} / \mathrm{S}$. Four mutations were recorded in ORF3/4a and 4 in ORF4b (Table 2). Of these, 3 mutations changed the corresponding amino acids in ORF3/4a; L8527F, A8552V, and S8596L and two in ORF4b; S8703T and M8723T. Both N and O glycosylation sites were determined for the $\mathrm{S}$ protein. A total of 13 potential $\mathrm{N}$-glycosylation sites, $66,104,125,166,222$, $236,244,410,487,592,619,719$, and 870 , were reported for all the tested strains including our strains. Only one strain, isolate 1390-Hu-Jed, isolated in March of 2019 in Jeddah displayed an additional $\mathrm{N}$-glycosylation site at 155. In the contrast, potential sites for O-glycosylation ranged from 2 to 4 . In most strains, residues 135 , and 878 seemed to be conserved for O-glycosylation.

\section{Codons under selective pressure}

The adaptive evolution of MERS-CoV strains was evaluated by calculating $\mathrm{dN} / \mathrm{dS}$ ratio $(\mathrm{w})$ for the entire amplified fragments. Most codons of the two major clades (A and $\mathrm{B}$ ) displayed purifying selection with $\mathrm{w}<1$ (0.329 for clade A and 0.438 for clade B). Only 5 codons, 4 in ORF1a (926, 1055, 2747 and 3785), and 1 in spike gene (7085) were found to have $w>1$ by the four different models, SLAC, FEL, REL and MEME with statistical significance values. 
Table 2 Mutation record analysis of MERS-CoV strains identified in the current study

\begin{tabular}{|c|c|c|c|c|c|c|c|}
\hline \multirow[t]{2}{*}{ Gene } & \multirow[t]{2}{*}{ Mutation } & \multirow[t]{2}{*}{ Amino acid change } & \multirow{2}{*}{$\begin{array}{l}\text { Positive/ } \\
\text { negative } \\
\text { selection }\end{array}$} & \multicolumn{4}{|l|}{ Saudi MERS-CoV strains } \\
\hline & & & & Hu-Dammam_1_2015 & Hu-Dammam_2_2015 & Hu-Madinah_4_2015 & Hu-Riyadh_11_2014 \\
\hline ORF1a & C3442T & - & Positive & + & - & - & - \\
\hline ORF1a & C8518T & A2840V & Positive & + & + & + & + \\
\hline ORF1a & A8846G & - & Negative & - & - & + & - \\
\hline ORF1a & C8953Т & S2985F & - & - & - & + & - \\
\hline ORF1b & C19075A & - & Negative & + & + & + & + \\
\hline Spike & T21569C & - & - & + & - & - & - \\
\hline Spike & T21713C & - & - & - & + & + & + \\
\hline Spike & C22169T & - & - & - & - & - & + \\
\hline Spike & T22337C & - & - & + & - & - & - \\
\hline Spike & C22349T & - & Negative & + & - & + & - \\
\hline Spike & G22427T & - & - & + & - & - & - \\
\hline Spike & T22895C & - & Negative & + & - & - & - \\
\hline Spike & T23406C & - & - & + & - & - & - \\
\hline Spike & T23504C & - & - & - & + & + & + \\
\hline Spike & C23570T & - & Negative & - & + & + & + \\
\hline Spike & C23648T & - & Negative & - & + & + & + \\
\hline Spike & T23714G & - & - & + & - & - & - \\
\hline Spike & C23756T & - & Negative & - & + & + & + \\
\hline Spike & C23804T & - & - & - & + & + & + \\
\hline ORF3 & С25580T & L8527F & - & - & + & + & + \\
\hline ORF3 & $\mathrm{C} 25656 \mathrm{~T}$ & A8552V & - & + & - & - & - \\
\hline ORF3 & A25768T & - & Negative & - & + & + & + \\
\hline ORF3 & C25788T & S8596L & Positive & - & + & + & + \\
\hline ORF4+b & T26109C & S8703T & - & - & + & + & + \\
\hline ORF4b & G26167C & M8723T & - & + & - & - & - \\
\hline ORF4b & C26216T & - & - & - & + & - & - \\
\hline ORF4b & C26518T & - & - & + & - & - & - \\
\hline
\end{tabular}

\section{Phylogenetic analysis}

The phylogenetic tree was constructed based solely on the nucleotide sequence of the spike gene. MERS-CoV strains were clustered into three main clades, A, B and C (Fig. 3). Clade A has four strains including the first strain isolate from Bisha, Saudi Arabia in 2012, an early strain from Jordan, and two camel strains from UAE and Egypt. The majority of MERS-CoV strains are grouped into clade $B$ which is further divided into 4 distinctive lineages B1 to B4. Most of the Saudi strains, including those of the current study, are members of lineage B3. Strains from Korea and China are also grouped into lineage B3, whereas UAE strains of both human and camel origin are grouped in lineage B1. Clade C contains only three strains of camel origin isolated in Ethiopia in 2017.

\section{Discussion}

MERS-CoV continues to circulate in the Middle East region causing sporadic cases, particularly in Saudi Arabia. The extinction of SARS-CoV-1, the causative agent of 2002-2003's pandemic, the low spread rate of
MERS-CoV, and the emergence of the current SARSCoV-2 pandemic has raised several questions regarding coronavirus $(\mathrm{CoV})$ genetics and evolution. In the current study, we aimed at analyzing the sequence of four MERSCoV strains identified in the winter season of 2014-2015. These sequences were compared to a wide range of strains identified in both human and camel over 7 years (2012-2019). The use of concatenated sequences particularly those of the most important genes was found to be reliable for sequence and phylogenetic analysis of MERS$\mathrm{CoV}[34,35]$.

One of the interesting features of CoVs is its ability to use different cellular receptors. For instance, $\mathrm{HCoV}-229 \mathrm{E}$ uses Aminopeptidase N [36], SARS-CoV-1 and SARSCoV-2 use angiotensin-converting enzyme 2 (ACE2) [37], whereas $\mathrm{S}$ protein of MERS-CoV binds to dipeptidyl peptidase 4 (DPP4) [20]. The location of S protein on the surface of virus envelope and its role in initiating virus infection makes it a preferred target for host defense and consequently a major hot spot for mutation. In comparison to EMC-2012, the first identified MERS-CoV strain, 
(See figure on next page.)

Fig. 2 Deduced amino acid alignments of representative strains from different years were selected, and the alignment was done by Clustal W method running within the MegAlign program (DNAstar). Alignments are shown in comparison with the consensus sequences of the first isolated MERS-CoV strain (EMC-2012). Dots represent the identical amino acid residues. a displays 80 deduced amino acids of the S protein RBD. Host and year specific amino acids are shown in boxes. $\mathbf{b} 90$ amino acid residues of ORF1a/b (residues 1025 to 1105) showed a distinct pattern where several amino acids had been changed permanently in comparison with the isolate (EMC-2012); 1000 T/N, 1055 P/S, 1070 A/E, 1094 N/S

several characteristic amino acid changes were reported along the $\mathrm{S}$ gene including the RBD. These changes appear to be host and year specific. The host specificity of these amino acid changes in RBD may reflect adaptation to human or camel cellular receptors. Whereas year specific changes reflect continuous accumulation of mutations over time to coup with the immune response, only one codon of the $\mathrm{S}$ gene was found to be under selective pressure. In contrast, RSV and influenza viruses evolve mainly by introducing several point mutations in the attachment and hemagglutinin proteins, respectively. This finding adds more evidence that CoVs evolve by introducing major changes in the $\mathrm{S}$ gene through recombination rather than accumulation of point mutations. Glycosylation of viral glycoproteins usually modulate virus infectivity and antigenicity [38, 39]. Both $\mathrm{N}$ - and O-linked oligosaccharides may mask epitopes in certain cases and hence enables the virus to escape the immune system [40, 41]. In a previous study, we have reported that the variation in the glycosylation pattern of Saudi HRSV-A strains had a deep impact on virus infectivity and immunogenicity [42]. Here, we report a total of 13 potential N-glycosylation and from 2 to 4 O-linked glycosylation sites in the spike protein. These glycosylation sites may enhance virus infectivity and help to evade the pre-existing immunity.The drawback of the present study is the limited number of specimens used for analysis. Although a few number of (partial) sequence has been used, the data are still relevant and indicative. Even though the whole genome sequence is variable, however, the fragments included in the study are the most variable and therefore more suitable for studying virus evolution overtime. From our bioinformatic analysis of the entire MERS-CoV genome, we do not expect $a$ significant difference in the results.

The relationship between different strains of MERS$\mathrm{CoV}$ at the level of geographical distribution and host range (i.e. camel or human) was further elucidated in phylogenetic analysis. Although we used partial sequence of $\mathrm{S}$ gene $(2670 \mathrm{nt})$, the tree topology was almost similar to that constructed using complete $S$ gene and full genome sequences [43-46]. Because of the high sequence similarity between MERS-CoV strains of camel and human origins, clades displayed a mix of both. In a previous study, Lau et al., has classified the MERS-CoV strains into two major clades, A and B [43]. In this study, inclusion of MERS-CoV strains isolated from Ethiopian camels has resulted in appearance of a third clade $(C)$. Clade $\mathrm{C}$ was recognized before to contain isolates from Ethiopia, Burkina Faso, Egypt, Morocco, and Nigeria, and therefore, it may be considered as an African clade [44].

MERS-CoV is largely circulating among dromedary camels in the Middle East region and in North and East Africa as evidenced by the high seropositive rates in many of the affected countries [47, 48]. However, human cases were not reported in most of the African countries and remained confined only to the Middle East region. This may be explained by the antigenic variation between the $\mathrm{S}$ protein of MERS-CoV isolated from dromedaries in Ethiopia and those isolated from the Middle East. Another explanation is that MERS$\mathrm{CoV}$ strains of Ethiopian camels replicate at lower rates in tissue culture and are easily neutralized by lower concentration of sera [44].

Lineage B3 comprises most strains isolated in Saudi Arabia as well as in South Korea and China [49]. The virus was reportedly transmitted to South Korea via a Korean who performed multiple visits to the Middle East countries including Saudi Arabia. Interestingly, the same strain was transmitted to China via two infected persons who travelled from South Korea [50].

Accessory proteins play an important role in the pathogenesis of MERS-CoV. For example, the product of ORF4a inhibits interferon production through binding to dsRNA while the product of ORF4b mediate virus evasion of IFN actions [51, 52]. Therefore, amino acid changes in both ORFs may modulate the host immune response against MERS-CoV. Here, we reported four mutations in each ORF with amino acid changes in the corresponding codons. However, the impact of these amino acid changes on virus pathogenicity requires further studies.

\section{Conclusion}

In conclusion, sequence and phylogenetic analysis of MERS-CoV overtime from 2012 to 2019 revealed the continuous evolution of the virus. MERS-CoV evolution was apparent in both ORF1a/b and the $S$ gene. Interestingly, amino acid changes seemed to be host and 


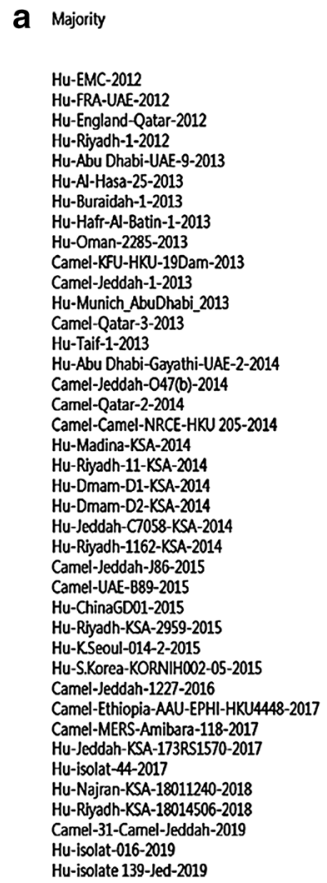

b Majority

\section{Hu-EMC-2 012}

Hu-Bisha 12012

Hu-Riyadh 12012

Hu-FRA UAE $\overline{2} 012$

Hu-Jordan N 32012

Abu Dhabi_UAE_9_2013

Camel-Egypt-NRCE-HKU270-2013

Camel-KFU HKU 19 Dam-2013

$\mathrm{Hu}-\mathrm{Al}-\mathrm{Ha}$ sa $17-20 \overline{13}$

$\mathrm{Hu}-\mathrm{Al}-\mathrm{Ha}$ sa 252013

Hu-Munich_ĀbuDhabi_2013

Hu-Riyadh 142013

Hu-Riyadh 42013

Hu-Taif 12013

Hu Oman $2 \overline{2} 852013$

Camel-Ri yadh-RY136 2014

Camel Jeddah O23(b) 2014

Camel_Jeddah_047(b)_2014

Hu-Damam-1-2014

Hu-Damam-2-2014

Hu-Jeddah_C10306_KSA_2014

Hu-Makkah_KSA_C9 $\overline{3} 55-\overline{2} 014$

Hu-Riyadh-11-2014

Hu-Riyadh KSA $683 \quad 2014$

Camel-B. Faso-

Camel-UAE-B60-2015

Camel-UAE-B61-2015

Hu-KFMC $10 \quad 2015$

Hu-KFMC 12015

Hu-K Seoul 16812015

Hu-Oman-50-2015

Hu-Riyadh-KSA-031D1N-2015

Hu-S-Korea KORKNIH $002 \quad 052015$

Hu_Riyadh_KSA_2959_2015

Hu-Riyadh-KSA-12160-2016

Hu-Riyadh-KSA-13798-2016

Camel-Ethiopi a-AAU-EPHI-HKU 44 48-2017

Camel-MERS-Amibara-126-2017

Hu-Jeddah-KSA-173RS1101-2017

Hu-Albaha-KSA-0800H-2018

Hu-Qaseem-KSA-18013897-2018

Hu-Riyadh-KSA-1801 4506-2018

Hu-isolate-016-2019

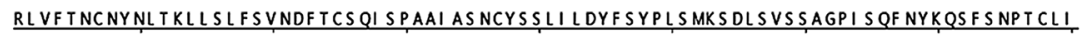

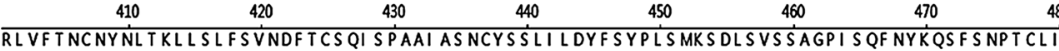

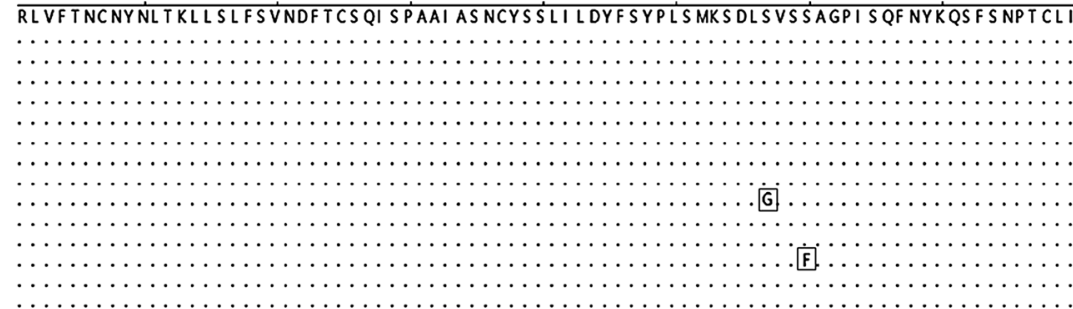

安.

宦

这.

i்.

F

宁

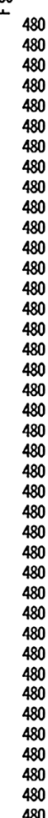

DEAEDVTESVQEEAQPVEVPVEDIAQVIADTLQETPVVSDTVEVPPQVVKLPSEPQT IQPEVKEVAPVYEADTEQTQSVTVKPKRLRKK

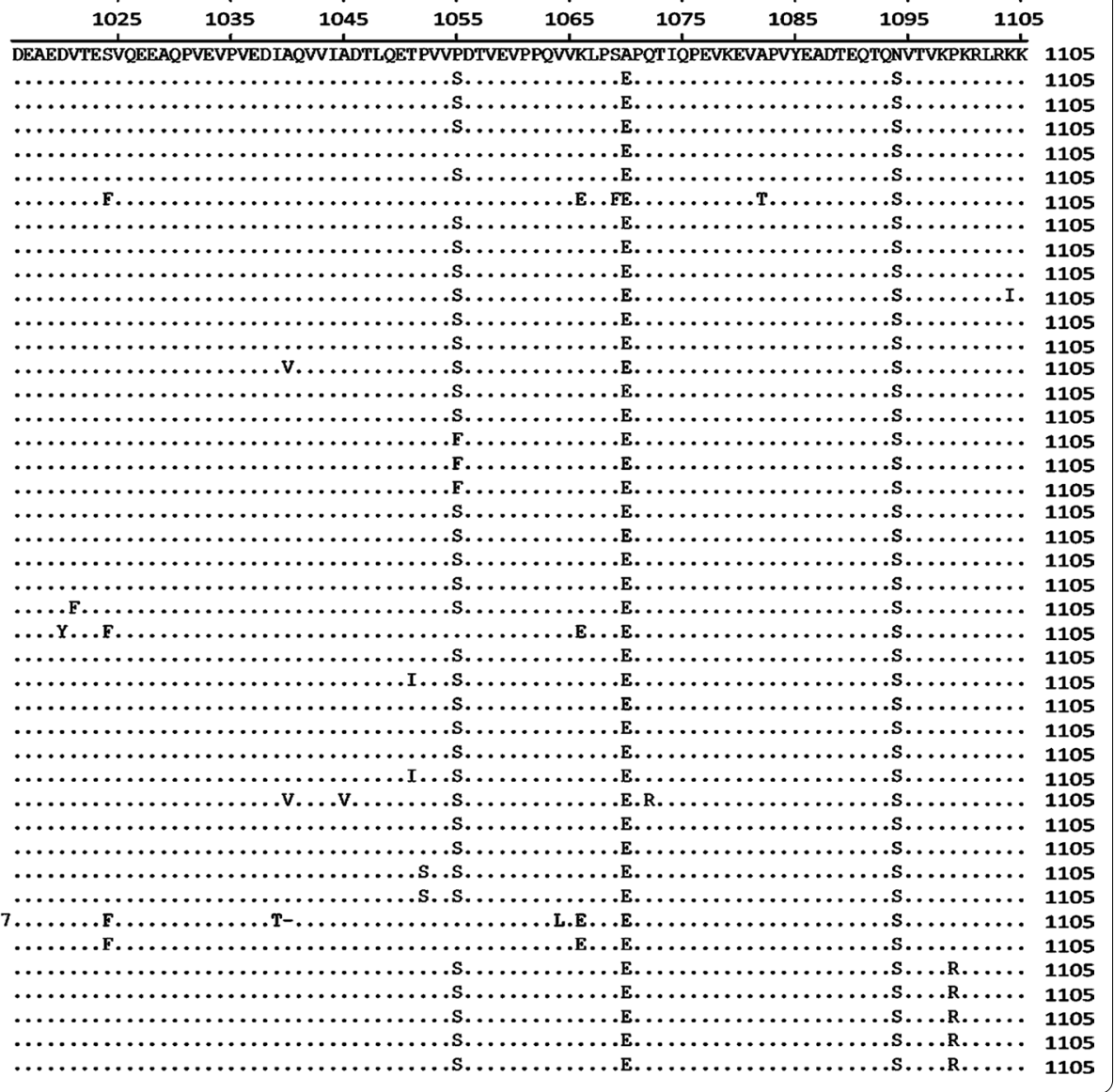




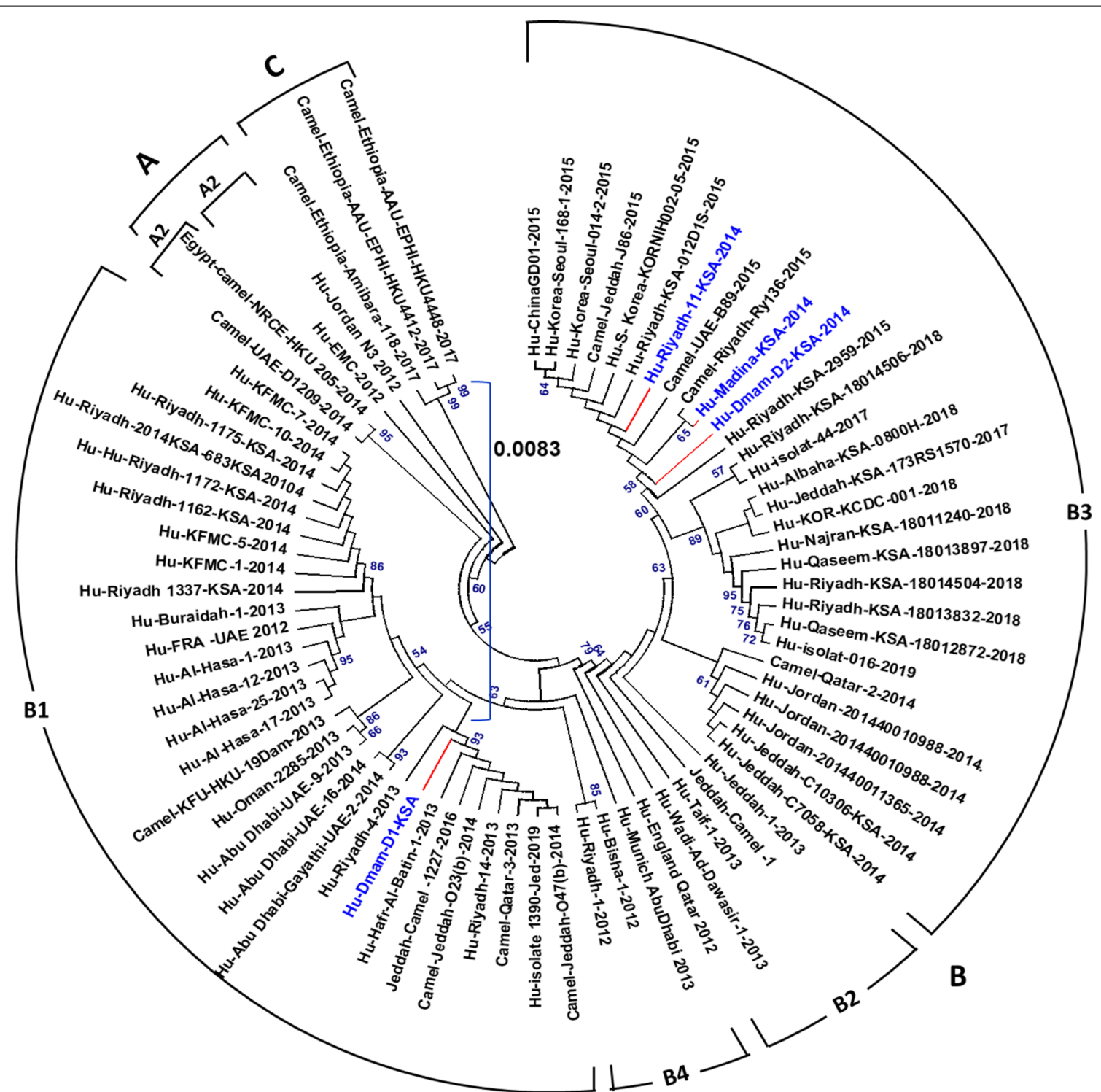

Fig. 3 Phylogenetic tree based on the first $2670 \mathrm{nt}$ of the S gene using MEGA 6.06 program. Multiple sequence alignment was performed using Clustal W, and the phylogram was generated by the Maximum Likelihood method based on the Tamura-Nei model. The analysis involved 73 nucleotide sequences. All positions containing gaps and missing data were eliminated. Only bootstrap values exceeding $50 \%$ are displayed. Clades and lineages are indicated at the periphery of the phylogram

year specific reflecting virus adaptation to host cellular receptors and evolution overtime to coup with the host immunity. Taking into consideration the inconsistent epidemiological patterns of $\mathrm{HCoVs}$, we recommend frequent monitoring the sequences of MERS-CoV isolates particularly the $\mathrm{S}$ protein and understand these changes with regard to disease severity. Deep understanding of virus evolution will be useful to contain and develop effective tools for controlling any possible MERSCoV outbreak at early stages.

\section{Abbreviations}

MERS-CoV: Middle East Respiratory Syndrome-related Coronavirus; CoVs: Coronaviruses

\section{Acknowledgements}

The authors thank Deanship of Scientific Research, KSU for technical support.

\section{Authors' contributions}

MF, HA, FA designed the study, MF,AH, RB perfomed the experiments and wrote the manuscript. All authors read and approved the final manuscript.

\section{Funding}

This study was supported by the researchers supporting project number (RSP2020/198), King Saud University, Riyadh, Saudi Arabia. 


\section{Availability of data and materials}

Samples were collected and handled by the relevant authorities at the Saudi Ministry of Health ( $\mathrm{MOH}-\mathrm{SA})$ following the strict biosafety guidelines set by $\mathrm{WHO}$ and CDC $[7,27]$. Samples were transported in viral transport medium to the regional laboratories of $\mathrm{MOH}-\mathrm{SA}$ and processed immediately or stored at $-80^{\circ} \mathrm{C}$ till use.

\section{Declarations}

\section{Ethics approval and consent to participate}

Informed consents were obtained from the patients or their guardians and the study protocols were prepared to conform to the 1975 Declaration of Helsinki.

\section{Consent for publication}

Informed consents were obtained from the patients or their guardians for performing and publishing the results to conform to the 1975 Declaration of Helsinki

\section{Competing interests}

The authors declare that they have no competing interests.

\section{Author details}

'Department of Botany and Microbiology, College of Science, King Saud University, Riyadh 11451, Saudi Arabia. ${ }^{2}$ Department of Virology, Faculty of Veterinary Medicine, Cairo University, Giza 12211, Egypt.

Received: 28 February 2021 Accepted: 22 April 2021

Published online: 30 April 2021

\section{References}

1. Perlman S. Pathogenesis of coronavirus-induced infections. Review of pathological and immunological aspects. Adv Exp Med Biol. 1998:440:503-13.

2. Weiss SR, Navas-Martin S. Coronavirus pathogenesis and the emerging pathogen severe acute respiratory syndrome coronavirus. Microbiol Mol Biol Rev. 2005;69(4):635-64. https://doi.org/10.1128/MMBR.69.4.635-664. 2005.

3. Lam WK, Zhong NS, Tan WC. Overview on SARS in Asia and the world. Respirology. 2003;8 Suppl(Suppl 1):S2-5. https://doi.org/10.1046/j.14401843.2003.00516.x.

4. Zaki AM, van Boheemen S, Bestebroer TM, Osterhaus ADME, Fouchier RAM. Isolation of a novel coronavirus from a man with pneumonia in Saudi Arabia. N Engl J Med. 2012;367(19):1814-20. https://doi.org/10. 1056/NEJMoa1211721.

5. Assiri A, Al-Tawfiq JA, Al-Rabeeah AA, et al. Epidemiological, demographic, and clinical characteristics of 47 cases of Middle East respiratory syndrome coronavirus disease from Saudi Arabia: a descriptive study. Lancet Infect Dis. 2013;13(9):752-61. https://doi.org/10.1016/S14733099(13)70204-4.

6. Cauchemez S, Van Kerkhove MD, Riley S, Donnelly CA, Fraser C, Ferguson NM. Transmission scenarios for Middle East Respiratory Syndrome Coronavirus (MERS-CoV) and how to tell them apart. Euro Surveill. 2013;18(24):20503.

7. $\mathrm{WHO}$ | Laboratory testing for Middle East Respiratory Syndrome Coronavirus. WHO. Accessed November 20, 2020. http://www.who.int/csr/disea se/coronavirus_infections/mers-laboratorytesting/en/

8. Woo PCY, Wang M, Lau SKP, et al. Comparative analysis of twelve genomes of three novel group $2 \mathrm{c}$ and group $2 \mathrm{~d}$ coronaviruses reveals unique group and subgroup features. J Virol. 2007;81(4):1574-85. https:// doi.org/10.1128/JVI.02182-06.

9. Li W, Zhang C, Sui J, et al. Receptor and viral determinants of SARS-coronavirus adaptation to human ACE2. EMBO J. 2005;24(8):1634-43. https:// doi.org/10.1038/sj.emboj.7600640.

10. Lau SKP, Fan RYY, Luk HKH, et al. Replication of MERS and SARS coronaviruses in bat cells offers insights to their ancestral origins. Emerging Microbes Infect. 2018;7(1):1-11. https://doi.org/10.1038/ s41426-018-0208-9.
11. Buchholz U, Müller MA, Nitsche A, et al. Contact investigation of a case of human novel coronavirus infection treated in a German hospital, October-November 2012. Euro Surveill. 2013;18(8):20406.

12. Meyer B, Müller MA, Corman VM, et al. Antibodies against MERS Coronavirus in Dromedary Camels, United Arab Emirates, 2003 and 2013. Emerg Infect Dis. 2014;20(4):552-9. https://doi.org/10.3201/eid2004.131746.

13. Lau SKP, Li KSM, Tsang AKL, et al. Genetic characterization of betacoronavirus lineage $C$ viruses in bats reveals marked sequence divergence in the spike protein of pipistrellus bat coronavirus HKU5 in japanese pipistrelle: implications for the origin of the novel middle east respiratory syndrome coronavirus. J Virol. 2013;87(15):8638-50. https://doi.org/10.1128/JVI. 01055-13.

14. de Groot RJ, Baker SC, Baric RS, et al. Middle east respiratory syndrome coronavirus (MERSCoV): announcement of the coronavirus study group. J Virol. 2013;87(14):7790-2. https://doi.org/10.1128/JVI.01244-13.

15. Woo PCY, Lau SKP, Lam CSF, et al. Discovery of seven novel mammalian and avian coronaviruses in the genus deltacoronavirus supports bat coronaviruses as the gene source ofalphacoronavirus and betacoronavirus and avian coronaviruses as the gene source of gammacoronavirus and deltacoronavirus. J Virol. 2012;86(7):3995-4008. https://doi.org/10. 1128/JVI.06540-11.

16. van Boheemen S, de Graaf M, Lauber C, et al. Genomic characterization of a newly discovered coronavirus associated with acute respiratory distress syndrome in humans. MBio. 2012. https://doi.org/10.1128/mBio. 00473-12.

17. Snijder EJ, Bredenbeek PJ, Dobbe JC, et al. Unique and conserved features of genome and proteome of SARS-coronavirus, an early split-off from the coronavirus group 2 lineage. J Mol Biol. 2003;331(5):991-1004. https://doi org/10.1016/S0022-2836(03)00865-9.

18. Gorbalenya AE, Enjuanes L, Ziebuhr J, Snijder EJ. Nidovirales: Evolving the largest RNA virus genome. Virus Res. 2006;117(1):17-37. https://doi.org/ 10.1016/j.virusres.2006.01.017.

19. Chan JF-W, Chan K-H, Choi GK-Y, et al. Differential cell line susceptibility to the emerging novel human betacoronavirus 2C EMC/2012: implications for disease pathogenesis and clinical manifestation. J Infect Dis. 2013;207(11):1743-52. https://doi.org/10.1093/infdis/jit123.

20. Raj VS, Mou H, Smits SL, et al. Dipeptidyl peptidase 4 is a functional receptor for the emerging human coronavirus-EMC. Nature. 2013;495(7440):251-4. https://doi.org/10.1038/nature12005.

21. Zeng Q, Langereis MA, van Vliet ALW, Huizinga EG, de Groot RJ. Structure of coronavirus hemagglutinin-esterase offers insight into corona and influenza virus evolution. Proc Natl Acad Sci USA. 2008;105(26):9065-9. https://doi.org/10.1073/pnas.0800502105.

22. Woo PCY, Lau SKP, Huang Y, Yuen K-Y. Coronavirus diversity, phylogeny and interspecies jumping. Exp Biol Med (Maywood). 2009;234(10):111727. https://doi.org/10.3181/0903-MR-94.

23. Lau SKP, Lee $P$, Tsang AKL, et al. Molecular epidemiology of human coronavirus OC43 reveals evolution of different genotypes over time and recent emergence of a novel genotype due to natural recombination. J Virol. 2011;85(21):11325-37. https://doi.org/10.1128/JVI.05512-11.

24. Annan A, Baldwin HJ, Corman VM, et al. Human betacoronavirus $2 \mathrm{C}$ EMC/2012-related viruses in bats, Ghana and Europe. Emerg Infect Dis. 2013;19(3):456-9. https://doi.org/10.3201/eid1903.121503.

25. Drexler JF, Corman VM, Drosten C. Ecology, evolution and classification of bat coronaviruses in the aftermath of SARS. Antiviral Res. 2014:101:45-56. https://doi.org/10.1016/j.antiviral.2013.10.013.

26. Anthony SJ, Ojeda-Flores R, Rico-Chávez O, et al. Coronaviruses in bats from Mexico. J Gen Virol. 2013;94(Pt 5):1028-38. https://doi.org/10.1099/ vir.0.049759-0.

27. MERS-CoV | Interim Guidelines for Clinical Specimens from PUI |CDC. Published March 23, 2020. Accessed November 20, 2020. https://www. cdc.gov/coronavirus/mers/guidelines-clinicalspecimens.html.

28. Corman VM, Eckerle I, Bleicker T, et al. Detection of a novel human coronavirus by real-time reverse-transcription polymerase chain reaction. Euro Surveill. 2012. https://doi.org/10.2807/ese.17.39.20285-en.

29. Cotten M, Watson SJ, Kellam P, et al. Transmission and evolution of the Middle East respiratory syndrome coronavirus in Saudi Arabia: a descriptive genomic study. Lancet. 2013;382(9909):1993-2002. https://doi.org/ 10.1016/S0140-6736(13)61887-5. 
30. Smits SL, Raj VS, Pas SD, et al. Reliable typing of MERS-CoV variants with a small genome fragment. J Clin Virol. 2015;64:83-7. https://doi.org/10. 1016/j.jcv.2014.12.006.

31. Steentoft C, Vakhrushev SY, Joshi HJ, et al. Precision mapping of the human O-GalNAc glycoproteome through SimpleCell technology. EMBO J. 2013;32(10):1478-88. https://doi.org/10.1038/emboj.2013.79.

32. Pond SLK, Frost SDW. Datamonkey: rapid detection of selective pressure on individual sites of codon alignments. Bioinformatics. 2005:21(10):2531-3. https://doi.org/10.1093/bioinformatics/bti320.

33. Weaver S, Shank SD, Spielman SJ, Li M, Muse SV, Kosakovsky Pond SL. Datamonkey 2.0: a modern web application for characterizing selective and other evolutionary processes. Mol Biol Evol. 2018;35(3):773-7. https:// doi.org/10.1093/molbev/msx335.

34. Nowotny N, Kolodziejek J. Middle East respiratory syndrome coronavirus (MERS-CoV) in dromedary camels, Oman, 2013. Euro Surveill. 2014;19(16):20781.

35. Haagmans BL, Al Dhahiry SH, Reusken CB, Raj VS, Galiano M, Myers R, et al. Middle East respiratory syndrome coronavirus in dromedary camels: an outbreak investigation. Lancet Infect Dis. 2014;14(2):140-5.

36. Hofmann $\mathrm{H}$, Simmons $\mathrm{G}$, Rennekamp AJ, et al. Highly conserved regions within the spike proteins of human coronaviruses 229E and NL63 determine recognition of their respective cellular receptors. J Virol. 2006;80(17):8639-52. https://doi.org/10.1128/JVI.00560-06.

37. Walls AC, Park Y-J, Tortorici MA, Wall A, McGuire AT, Veesler D. Structure, function, and antigenicity of the SARS-CoV-2 spike glycoprotein. Cell. 2020;181(2):281-292.e6. https://doi.org/10.1016/j.cell.2020.02.058.

38. Lambert DM. Role of oligosaccharides in the structure and function of respiratory syncytial virus glycoproteins. Virology. 1988;164(2):458-66. https://doi.org/10.1016/0042-6822(88)90560-0.

39. Palomo C, García-Barreno B, Peñas C, Melero JA. The G protein of human respiratory syncytial virus: significance of carbohydrate side-chains and the C-terminal end to its antigenicity. J Gen Virol. 1991;72(Pt 3):669-75. https://doi.org/10.1099/0022-1317-72-3-669.

40. Cane PA, Matthews DA, Pringle CR. Identification of variable domains of the attachment (G) protein of subgroup A respiratory syncytial viruses. J Gen Virol. 1991;72(9):2091-6. https://doi.org/10.1099/ 0022-1317-72-9-2091.

41. Roca A, Loscertales M-P, Quintó L, et al. Genetic variability among group $A$ and $B$ respiratory syncytial viruses in Mozambique: identification of a new cluster of group B isolates. J Gen Virol. 2001;82(Pt 1):103-11. https:// doi.org/10.1099/0022-1317-82-1-103.

42. Farrag MA, Amer HM, Aziz IM, Alsaleh AN, Almajhdi FN. The emergence of subgenotype ON-1 of Human orthopneumovirus type A in Riyadh, Saudi Arabia: a new episode of the virus epidemiological dynamic. J Med Virol. 2020;92(8):1133-40. https://doi.org/10.1002/jmv.25643.
43. Lau SKP, Wong ACP, Lau TCK, Woo PCY. Molecular evolution of MERS coronavirus: dromedaries as a recent intermediate host or long-time animal reservoir? Int J Mol Sci. 2017. https://doi.org/10.3390/ijms18102138.

44. Shirato K, Melaku SK, Kawachi K, et al. Middle east respiratory syndrome coronavirus in dromedaries in ethiopia is antigenically different from the middle east isolate EMC. Front Microbiol. 2019. https://doi.org/10.3389/ fmicb.2019.01326.

45. Sohrab SS, Azhar El. Genetic diversity of MERS-CoV spike protein gene in Saudi Arabia. J Infect Public Health. 2020;13(5):709-17. https://doi.org/10. 1016/j.jiph.2019.11.007.

46. AlBalwi MA, Khan A, AIDrees M, et al. Evolving sequence mutations in the Middle East Respiratory Syndrome Coronavirus (MERS-CoV). J Infect Public Health. 2020;13(10):1544-50. https://doi.org/10.1016/j.jiph.2020.06. 030.

47. Müller MA, Corman VM, Jores J, et al. MERS Coronavirus Neutralizing Antibodies in Camels, Eastern Africa, 1983-1997. Emerg Infect Dis. 2014;20(12):2093-5. https://doi.org/10.3201/eid2012.141026.

48. Fukushi S, Fukuma A, Kurosu T, et al. Characterization of novel monoclonal antibodies against the MERS-coronavirus spike protein and their application in species-independent antibody detection by competitive ELISA. J Virol Methods. 2018;251:22-9. https://doi.org/10.1016/j.jviromet. 2017.10.008.

49. Cowling BJ, Park M, Fang VJ, Wu P, Leung GM, Wu JT. Preliminary epidemiologic assessment of MERS-CoV outbreak in South Korea, May-June 2015. Euro Surveill. 2015;20(25). Accessed November 20, 2020. https:// www.ncbi.nlm.nih.gov/pmc/articles/PMC4535930/.

50. Wang Y, Liu D, Shi W, et al. Origin and possible genetic recombination of the middle east respiratory syndrome coronavirus from the first imported case in China: phylogenetics and coalescence analysis. MBio. 2015;6(5):e01280-e1215. https://doi.org/10.1128/mBio.01280-15.

51. Totura AL, Baric RS. SARS coronavirus pathogenesis: host innate immune responses and viral antagonism of interferon. Curr Opin Virol. 2012;2(3):264-75. https://doi.org/10.1016/j.coviro.2012.04.004.

52. Yang $Y$, Ye F, Zhu N, et al. Middle East respiratory syndrome coronavirus ORF4b protein inhibits type I interferon production through both cytoplasmic and nuclear targets. Sci Rep. 2015;5:17554. https://doi.org/10. 1038/srep17554.

\section{Publisher's Note}

Springer Nature remains neutral with regard to jurisdictional claims in published maps and institutional affiliations.
Ready to submit your research? Choose BMC and benefit from:

- fast, convenient online submission

- thorough peer review by experienced researchers in your field

- rapid publication on acceptance

- support for research data, including large and complex data types

- gold Open Access which fosters wider collaboration and increased citations

- maximum visibility for your research: over $100 \mathrm{M}$ website views per year

At BMC, research is always in progress.

Learn more biomedcentral.com/submissions 